\title{
AZ MTMI TUDOMÁNYTERÜLET IRÁNTI ÉRDEKLŐDÉS VÁLTOZÁ- SÁNAK VIZSGÁLATA DIGITÁLIS TANULÁSI KÖRNYEZETBEN
}

\author{
Lengyelné Szilágyi Szilvia \\ egyetemi docens, Miskolci Egyetem, Matematikai Intézet, Analizis Tanszék \\ 3515 Miskolc, Miskolc-Egyetemváros, e-mail: matszisz@uni-miskolc.hu
}

Szepesiné Medve Judit

biológia-kémia szakos középiskolai tanár, Földes Ferenc Gimnázium

3525 Miskolc, Kelemen Didák u. 5., e-mail: macijuci2@gmail.com

\begin{abstract}
Absztrakt
Cikkünkben annak a felmérésnek az eredményeit mutatjuk be, amelyet 2021 februárjában végeztünk 15-16 éves, gimnáziumban tanuló diákok körében a természettudományos tárgyak (matematika, biológia, kémia, fizika) online tanulási-tanitási folyamatának kapcsán a koronavirus járvány második hulláma alatt.
\end{abstract}

Kulcsszavak: online tanulás, online tanitás, természettudományos tantárgyak, koronavírus világjárvány

\begin{abstract}
In our paper we present the results of a research conducted in February 2021 among 15-16-year-old high school students in connection with the online learning-teaching process of science subjects (mathematics, biology, chemistry, physics) during the second wave of coronavirus pandemic.
\end{abstract}

Keywords: online learning, online teaching, science subjects, coronavirus pandemic

\section{Bevezetés}

Az elmúlt évtizedben az MTMI szakok iránti érdeklődés rohamos csökkenésének lehettünk szemtanúi Magyarországon. Sajnálatos tény, hogy nem olyan mértékben jelentkeznek a továbbtanulók a matematikai, természettudományos, müszaki vagy informatikai - összefoglaló rövidítéssel MTMI - képzésekre, amilyen mértékben a hazai munkaerőpiaci szereplök igénye azt megkívánná. Az MTMI végzettségü munkavállalók hiánya fenyegető árnyékot vet a gazdaság stabilitására és a modernizáció, a felzárkózás lehetőségét is erősen veszélyezteti. A felsőoktatásba jelentkezők és a felvettek száma az MTMI szakok tekintetében országosan egyaránt stagnáló, vagy csökkenő tendenciát mutat, így nincs valódi verseny a bekerülésért. Az egyetemi oklevelek kibocsátási mennyiségét a rendkívül magas lemorzsolódás is csökkenti [1]. Ezek az általános megállapítások sajnos a Miskolci Egyetem vonatkozásában is igazak. Tény, hogy a pénzügyi vezetők és elemzők várakozásait egyaránt alaposan átalakította a 2020 tavaszán Magyarországon is veszélyhelyzet kihirdetését követelő világjárvány. A külső kockázatok között a szakemberhiányt megelözte a gazdasági bizonytalanság [2]. Ennek ellenére az MTMI területeken jelentkező szakemberhiány problémája nem söpörhető a szőnyeg alá.

Fontos, hogy a felsőoktatási intézményeknek folyamatosan a valós helyzetet tükröző képük legyen az MTMI szakokra várhatóan belépő diákok attitüdjeiről, elvárásairól. A felsőoktatás, amely a társadalom egyik legnagyobb alrendszere, ha lassan is, de igazodik az elvárásokhoz. Ki gondolta volna, hogy 2020 tavaszán egyik napról a másikra át kell állni online oktatásra a koronavírus-járvány miatti korlá- 
tozások miatt? A járvány okozta rendkívüli helyzetben is tovább kellett és kell ma is müködtetni az oktatási rendszert. A tanulás zavartalanságának érdekében elengedhetetlen a megfelelő feltételek biztosítása. A távoktatásra való gyors áttérés jelentős kihívások elé állította az intézményeket, a tanárokat és a diákokat egyaránt.

Cikkünkben egy 2021 februárjában végzett felmérés eredményeit mutatjuk be. 15-16 éves, gimnáziumban tanuló diákokat kérdeztünk meg a természettudományos tárgyak (matematika, biológia, kémia, fizika) online tanulási-tanítási folyamatának kapcsán. A megkérdezett tanulók 2019 szeptemberében kezdték meg középiskolai tanulmányaikat, így a 2020 márciusában átmenet nélkül bevezetett online oktatásnak 9. évfolyamos tanulóként voltak részesei. Tavaly tavasszal és nyáron majdnem négy hónapig folyt oktatásuk online környezetben, majd 10. évfolyamos diákként 2020 novemberétől újra. Az MTMI szakok iránti érdeklődés nagyobb százalékban van jelen azoknál a diákoknál, akik már középiskolás éveik alatt is magasabb óraszámban tanulnak természettudományos tárgyakat. A felmérés során ezért olyan tanulókat is megkérdeztünk, akik tagozaton tanulnak. Kontrollként közel ugyanannyi alaptanterv szerint haladó diák is a felmérés célcsoportjába került. Az alaptanterv szerint haladók hatosztályos képzésben vesznek részt, tanáraikkal jobban összeszoktak, hiszen két évvel korábban kezdték meg tanulmányaikat az intézményben.

\section{A felmérés általános jellemzői és számszerü adatai}

Írásbeli megkérdezés módszerével folytattuk le a felmérést. A választott kutatási forma alkalmazása mellett nemcsak az a realitás szólt, hogy a járványhelyzet miatt a személyes kontaktusok számát célszerü minimalizálni, hanem az is lényeges szempont volt, hogy így kiiktatható a kérdező szubjektivitása. A kérdezettektől az otthoni, nyugodt körülmények közötti válaszadás lehetőségének megteremtésével átgondoltabb, körültekintőbb válaszokat vártunk. Ügyeltünk a kérdőív terjedelmére is. Szem előtt tartottuk, hogy a 15-16 éves kamaszok pár másodperc alatt döntik el, hogy mit méltatnak figyelemre és mi nem, továbbá a szabadidejük terhére végzendő plusz feladatokat sem veszik jónéven. Csupán nyolc kérdést fogalmaztunk meg a vizsgált témával kapcsolatban, abban a reményben, hogy ez a kérdésszám még nem veti vissza a válaszadási hajlandóságot.

78 diák kapta meg a nyolc kérdésből álló felmérést, ahol a feltett kérdésekre 2-3 mondatos válaszokat vártunk. A megkérdezett tanulók 51,28\%-a biológia vagy kémia tagozaton folytatja középiskolai tanulmányait, a többi alaptanterv szerint tanul. A kérdéseket tartalmazó docx formátumú file-t kitöltve a megkérdezettek 69,23\%-a küldte vissza e-mailben. Az 54 beérkezett válasz felét lány, felét pedig fiú küldte, tehát a nemi megoszlás egyenletes. A válaszokat visszaküldők 51,85\%-a tagozatos diák, míg $48,15 \%$ oktatása alaptanterv szerinti, tehát ez az eloszlás is közel egyenletes.

A megkérdezettek válaszadási motivációját nem befolyásoltuk, a docx file visszaküldésével semmilyen előnyre nem tett szert a választ beküldő. A diákok tudták, hogy a válaszadás önkéntes, és a visszajelzéseket név nélkül, bizalmasan kezeljük. Nem hangsúlyoztuk, hogy feltétlenül választ várunk a kérdőívekre, de a feltett kérdésekből egyértelmüen kiderült, hogy a válaszadó véleménye fontos a felmérés szempontjából. Úgy gondoljuk, hogy a magas válaszadási szám annak is köszönhető, hogy ez a két osztály még nem vett részt ilyen jellegü felmérésben, így nem jelentett terhet számukra a válaszok legépelése és elektronikus úton történő továbbítása.

Meglepően magas, 84,04\% azoknak a diákoknak a százalékos aránya, akik válaszoltak mind a nyolc feltett kérdésre. 5, 55\% adott választ hét, és ugyanennyi hat kérdésre választ. A legkevesebb válasz öt volt, ezt egyetlen beküldő szolgáltatta. A feltett kérdésekre kért, legalább 2-3 mondatban kifejtett választ a felmérésben aktívan résztvevők 64,81\%-ától kaptuk meg. A többiek $(35,19 \%)$ egy- 
szavas válaszokat adtak, vagy legfeljebb egy mondatban fogalmazták meg válaszaikat. A válaszok néhány kivételtől eltekintve relevánsak, informatívak. A tömör, lényegre törő válaszok 57,89\%-át a tagozaton tanulók adták. A természettudományos tárgyak iránt érdeklődő fiatalok esetén nem meglepő, hogy gondolataikat sallangok nélkül, velősen fejtik ki, amelyet a fenti adatok egyértelmüen mutatnak ilyen kis minta esetén is. A nemek szerinti eloszlást vizsgálva a részletes választ adók $65,71 \%$-a lány, míg a rövid, tömör válaszok $63,16 \%$-át adta fiú.

\section{A felmérés kérdései és a leggyakoribb válaszok}

Az első három kérdéssel a digitális oktatás előnyeit és hátrányait igyekeztünk feltárni, valamint a motiváció megvalósíthatóságának lehetőségeit 15-16 éves kamaszok esetén. Az általános kérdések után következtek az MTMI tudományterületekhez szorosabban kötődő, az aktuális helyzetről a valós kép kialakítását célzó kérdések. Az érdeklődési kör változására, a digitális környezetben való tanulásra, valamint a gyakran használt online platformok feltárására irányultak ezek a kérdések. Az utolsó, lezáró általános kérdéssel pedig az oktatást hátráltató tényezőket gyüjtöttük össze.

\subsection{A digitális oktatásra történő átállásnak milyen pozitív hatásai voltak?}

Erre a kérdésre minden válaszküldő reagált. A diákok szemszögéből egyértelmüen kiderül, hogy az alvásra fordítható időtöbblet rendkívül fontos számukra, ezt a válaszadók 59,26\%-a rögzítette válaszában. Bejáró tanuló esetén ez akár másfél-két órát is jelenthet naponta. „Többet alszok, ezért kipihentebb vagyok, és így jobban tudok figyelni órán." Ez a logikai láncban leírt előny hasonló megfogalmazással 8 beérkezett válaszban található meg. A megnövekedett szabadidőt is megbecsülik a diákok, 25 válaszban került rögzítésre ez a pozitív következmény. A saját időbeosztás, az önállóság, a kevesebb utazás és a tanulásra fordítható több idő gyakorisága a válaszokban szintén magas. A kevesebb stressz 7 válaszban szerepel. Meglepö, hogy a kisebb esély a megfertözödésre csupán egyetlen tanulónál olvasható. Feltételezzük, hogy abban az esetben, ha a kérdésekhez elöre rögzített lehetséges válaszokból jelölhették volna be a diákok a válaszokat, akkor szinte mindenkinél fellelhető lenne ez az előny. Most azonban nem voltak rögzített válaszok, mert arra voltunk kíváncsiak, hogy a 15-16 éves diákok milyen válaszokat adnak önállóan, instrukciók nélkül.

\subsection{Milyen nehézségekkel kellett megbirkózni az online oktatás kezdetekor? Melyek maradtak?}

Ezekre a kérdésekre is válaszolt minden résztvevö. A leggyakoribb válasz az egységes felület hiánya volt az online oktatás első ciklusában. A felmérésben résztvevők csaknem fele, 44,44\%-a rögzítette ezt a választ. ,,Türelmesnek kellett lennünk, amíg a tanárok is megtanulták a digitális felületeket használni. Egyszerre 5-6 platformon kellett jelen lennünk, mivel nem volt egységes felület. Ez mára már csak 1-2 platformot jelent és sokkal ügyesebbek lettek.” „Eleinte a tanárok azt a platformot használták a diákokkal való kapcsolatfelvételhez, amit ismertek, így a tanulóknak nagyon sok alkalmazást kellett figyelni." "Sok tanár nem tudta kezelni az online platformokat. Nekünk sem volt könnyü a helyzet, amikor 4-5 helyen egyszerre kaptunk feladatokat, és senki nem tudta, hogy éppen mit hova kell feltölteni.” Az alaptanterv szerint haladó, választ beküldő lányok 76,47\%-a jelölte meg az egységes felület hiányát, mint nehézséget. A tagozatos lányok esetén ez az érték alacsonyabb, kereken $50 \%$. Az alaptanterv szerint haladó fiúk 33,33\%-a adta meg válaszában ezt a problémát, míg a tagozatos fiúk csupán 16,67\%-a. Ez a nehézség már a múlté, ugyanis az intézmény 2020 szeptemberére egységesítette az online oktatáshoz alkalmazott platformot. Választásuk a Microsoft Teams-re esett, így átláthatóbbá vált a diákok számára a 2020 novemberében újrakezdődő távolléti oktatás. Az intézmény informatiku- 
sai a tanári igények felmérése után sorra vették a lehetséges megoldásokat. A chat alapú MS Teamsre azért esett a választás, mert minden elvárásnak eleget tesz. A kifejezetten csapatmunkára fejlesztett alkalmazás az oktatásban is megállja helyét, mert kialakíthatók benne az osztályokhoz tartozó csoportok, az értekezlet funkcióval az online óra képpel és hanggal megtartható, a képernyőmegosztással lehetőség van bemutatók, videók kivetítésére, tartalmak megosztására. Közösen szerkeszthető tartalmak létrehozását, szerkesztését is támogatja a felület, és a bekapcsolható létszám megfelel az iskolai körülményeknek. A kiadott feladatok jól áttekinthetők, és határidő is rögzíthető hozzájuk. A platform nagy előnye, hogy a Tisztaszoftver Program keretében minden tanuló és pedagógus számára ingyenesen elérhető. „Egyszerre több platformon kellett jelen lennünk, mivel nem volt egységes felület. Ez mára megoldódott."

Az internettel kapcsolatos problémák szintén hangsúlyosan jelennek meg a válaszokban, azonban csupán a választ adók 24,07\%-ánál. A fiúk 31,03\%-a, míg a lányok csupán 16\%-a gondolt erre a válaszadáskor. „A Teams néha bug-os lesz, nem enged csatlakozni az órára, vagy késve jelenit meg üzeneteket, feladatokat." Az internettel kapcsolatos gondok nem szüntek meg, a második hullám alatt is ugyanolyan fejtörést okozva a diákságnak, mint az első online oktatási időszak esetén. „Leginkább a Teams alkalmazás szokott lassan betölteni és nem megfelelöen müködni vagy egyáltalán nem müködni." „Valamilyen internet probléma miatt sokszor akadozott az óra, ami most is elöfordul, de nem annyira gyakran, mint a kezdetekkor.” „Nagyon fontos az internet stabil müködése."

Számos további nehézség is felsorolásra került az online oktatással kapcsolatban. Kitünik a válaszokból, hogy az iskola tágas épületének tanterme helyett egy szobában, a számítógép előtt magányosan ülni általában nem vonzó a diákok számára. „A tanórai jegyzetek mellett a házit is meg kell írni ugye, és mikor a kettö között alig van szünet és környezetváltozás, elmegy töle az ember kedve. A személyes kontakt, a társaság hiánya pedig eléggé lehangoló, így a motiváció is kisebb.” „Az egész napot kénytelen vagyok a gép elótt tölteni. Sokkal jobban magamra vagyok utalva a tanulást illetöen, de ezt meg lehet szokni. Viszont az egész napos bentlét most is kihivás." „Számomra a barátaimtól való távollét a legnehezebb.” „A baráti kapcsolatok fenntartása is nehezebb, mint amikor ott vagyunk egymás mellett az iskolában és egész nap beszélgetünk, igy online oktatásban van olyan, hogy napokig nem keressük a másikat.” „A legnehezebb az élö órák hiánya az online oktatásban. Sokkal kevésbé vagyunk a figyelésre kényszerítve, ezzel kevesebb már az órán megszerzett tudásunk lesz, amely segítené az egyéni munkát. " Ezek a problémák nyilvánvalóan most is fennállnak és csak a jelenléti oktatás újraindításával szüntethetők meg.

A , többet kérnek a tanárok” a válaszadók 9,25\%-ánál került leírásra és csak alaptanterv szerint haladó diákoknál jelentkezett. „A tanárok több feladatot adtak/adnak fel, mint a jelenléti oktatás esetén, igy a szabadidőnk a nullához konvergál.” „Néha többet várnak el a tanárok, mint amennyit általában. Ez ma már ritkán fordul elö." Az online térben eltöltött idővel arányosan mind a tanárok, mind a diákok rutinra tettek szert, javult a kétirányú kommunikáció, így a diákok túlterhelése mérséklődött. A tagozatos tanulók az emelt óraszámok miatt a jelenléti oktatásban is fokozottabb terhelést kaptak, így az online oktatásra történő áttéréskor sem érzékelték gondnak az esetlegesen megnövekedett követelményeket. Esetükben a problémát inkább a hatékonyság jelenti. Kizárólag tagozatos diákok rögzítették válaszaik között, hogy kevésbé hatékony az online oktatás. „Nehezebb megérteni az anyagot, mert nem látom át rendesen a magyarázatot." „Néhány tantárgyból a jelenléti oktatás hatékonyabb." Az online órán való jegyzetelés ugyancsak felsorolásra került a problémák listázásakor. Ez a nehézség csak lányoknál került beküldésre. A reál beállítottságú hallgatók általában kiválóan tanulnak hallás után. Ha ez kiegészül egy jó jegyzet készítésével, akkor számukra a jegyzetelés hatékony tanulássá válik. Amikor leírásra kerül a lényeg, annak nagy része rögtön meg is marad a fejben, így kevesebb 
energiát kell befektetni a tanulás önálló fázisában. Azok a diákok hiányolják leginkább a jelenléti oktatást, akik így tanulnak. A készen kapott elektronikus jegyzetekből messze nem profitálnak annyit, mint amikor az órán kézzel írt jegyzetet készítenek.

Nem minden diák számára megterhelő az online oktatás. Öten jelezték, hogy semmilyen gondjuk sincs ezzel a munkaformával. „Számomra nem igazán voltak nehézségek és szerencsére most sincsenek."

\subsection{A digitális tanulási környezetben a motivációt hogyan valósították meg tanáraitok?}

A választ küldők 90,74\%-a válaszolta meg a kérdést. Egyértelmúen kiderült, hogy a diákok nagyon fontosnak tartják a tanárokkal való beszélgetés lehetőségét, igénylik a biztatást, lelkesítést. A tanulási motivációt erősíti, ha a tanárral kialakított kapcsolat stabil. Fontos, hogy a tanár elérhető legyen a diákok számára, meghallgassa és kezelje problémáikat. „A legtöbb tanár azt mondja, hogy tanuljunk, mert ez is egyenértékü az iskolai tanitással és kitartást kívánnak." „Nem mindenki törekszik arra, hogy motiváljon minket, de akik igen, azok leginkább próbálnak kis beszélgetéssel tartani bennünk az eröt, tanácsokat adnak, de persze mindenkinek maga miatt kell, hogy tanuljon, mert a kiesett idöt senki sem hozza vissza." Szeretik, ha az online óráik meg vannak tartva, ez többüket motiválja is a tanulásra. „Nagyon sok online órát tartottak, melyek során mindig biztattak minket.”

A figyelem fenntartására, a tanulás megkönnyítésére vagy egyéb célból alkalmazott videók, interaktív tananyagok, online játékok, feladatok, gamifikált tartalmak célravezető motivációs eszközök. „, Igyekeznek interaktívvá tenni az órákat, és minél több embert felszólítani az órán. ” „Kivetitett anyagokkal, teljesithetö feladatokkal és határidőkkel motiválnak.” „Érdekes videókat küldenek az adott tananyagról.” „Rengeteg érdekes videóval, oldallal bövitették ki a tanórákat.” A Z generációs diákság az IKT eszközökkel remekül dolgozik, s ezt tanáraitól is elvárja.

A szükség és a kényszer nagy úr, a legtöbb hallgatót erösen motiválja a kemény tanulásra a közelgő leadási határidő, a dolgozat vagy a felelés gondolata. „Legjobban az motivál arra, hogy valamit rendesen megtanuljak, ha kamerás feleléssel le kell felelni belöle.” „Bekapcsolt kamerával feleltünk, irtunk dolgozatot." Két alaptanterv szerint haladó diák válaszában megjelenik az alternatív tanulási módszerek közül a csoportmunka. Ez az innovatív tanulási technika egyre nagyobb teret hódít napjainkban, ugyanis a $Z$ generációs fiatalok esetén kifejezetten hatékony módszertani eszköz [3]. Örömteli tény, hogy a diákok felismerték a csoportmunka motiváló funkcióját. „,Különböző tanulási formákkal (pl. csoportmunka) motiválnak a tanárok."

A kutatások jelenlegi álláspontja szerint a tanulási motiváció a tanulók egyéni céljaitól függ. Ez lehet az adott tananyag tényleges elsajátítása, a tudás megszerzése, vagy a megcélzott érdemjegy elérése. Nem csupán a diák céljai, a környezete és a pedagógus, hanem a tanuló maga, a tárgyalt tananyag, valamint a tanítás módszere is befolyásolja a motiváltsági szintet $[4,5]$. A motiváció rendkívüli komplexitása a kapott válaszokban is megmutatkozik. „Látva, hogy bizonyos tanárok minden tölük telhetöt megtesznek, hogy megkönnyitsék számunkra a helyzetet és a tananyagot tisztességesen átadják számunkra, ezzel minket diákokat is arra ösztönöznek, hogy kitartóan tanuljunk, segitsük egymást." „Gondolom nehéz ilyenkor egy tanárnak, de élö oktatáskor sem voltam motiváltabb, mint most. A diák motiváltsága nem csak a tanártól függ.” „Sokkal inkább azt érzem, hogy magamnak, magam miatt tanulok." 


\subsection{Változott-e a természettudományos tárgyak iránti érdeklődésetek az online tanulásra átté- rés után? Mi ennek az oka?}

Erre a kérdésre egy diák nem reagált, tehát 53 választ vizsgáltunk. A válaszadók 77,37\%-ának nem változott, 9,43\%-nak növekedett, míg 13,20\%-nak csökkent az érdeklődése a természettudományos tárgyak iránt. „Elötte is szerettem és most is. A számolási feladatokat nehezebb ilyenkor megérteni, de nem lehetetlen. Az oka? Elkötelezett vagyok a természet müködésének megértése iránt.” „Nem, nem változott, mindig is ugyanúgy érdekelt például a biológia és most, hogy online oktatásban vagyunk több idôt tudok rá szánni, hogy tanuljam és utána olvassak dolgoknak, amik érdekelnek engem ezzel a tantárggyal kapcsolatban.” „Nem változott, a biológia digitális oktatás elött és közben is érdekel. A többi természettudományi tantárgy pedig sosem volt a kedvencem.” „Én nem vettem észre változást. Kémiából például a reakciók megnézése jóval egyszerübb online körökben, bár a személytelenség miatt szerintem élőben sokkal érdekesebb, látványosabb." „Nem, de én eddig is szerettem ezeket a tantárgyakat. Az pozitivum, hogy a tanár az órai anyagot az órák után publikussá teszi és ez segít a vázlataim kiegészitésében. is.” „Nem változott, továbbra sem ezzel a tudományággal szeretném folytatni a tanulmányaimat. Ennek az az oka, hogy eddig is csak érdekességképpen tanultam."

A tagozatos diákok 92,86\%-ának megmaradt, vagy növekedett az érdeklődése, míg az alaptanterv szerint haladó tanulók esetén ez az érték $80 \%$. A legnagyobb csökkenés az alaptanterv szerint tanuló lányoknál látható. ,,Változott, igen. Úgy érzem nehezebben tudják megtartani a tanárok a figyelmünket, ezért az érdeklödés is folyamatosan lankad.” „Engem mindig inkább a humán tárgyak érdekeltek jobban, de a reál tantárgyakkal sincs sok nehézségem. Online oktatás alatt sokkal kevesebb motivációm van ezeknek a tanulására és még nehezebbé teszi, hogy nincsenek élö kísérletek vagy a tanár folyamatos odafigyelése a diákokra.'

A kapott válaszokból egyértelmủen kiderül, hogy az online oktatás a természettudományos tárgyak esetén nem egyenértékü a jelenléti oktatással. „Egyes tantárgyakból nagyon hiányzik a személyes kontaktus (pl. fizika).” „Ezen tantárgyakkal van a legnagyobb probléma online, a tanárok igyekezete ellenére nagyon nehéz ezeket tanulni." „Számomra nehezebb így tanulni, hogy nincs személyes kontaktusom a tanárokkal, szóval, ha változott is az érdeklödésem, inkább negatív irányba." „Van olyan természettudományi tantárgy, amit sokkal nehezebben értek meg, mint a hagyományos oktatás során." „, Biológiából sokkal jobb személyesen tanulni az anyagot, mert jobban átjön az információ, mint online oktatásban.” ", Soha nem voltam a természettudományi tárgyak kedvelöje, de igy online még roszszabb, hiszen semmilyen kísérletet nem tudunk csinálni."

A nehézségek ellenére pozitív irányú elmozdulás is mérhető volt. „Igen, mivel különbözö reakciók vagy kísérletek megnézésével jobban megtanulom a tananyagot. Néhány plusz anyagot egy-egy videó segitségével könnyebben megjegyzek." Tény, hogy csak néhány diák számolt be arról, hogy az elmúlt időszakban jobban kezdték érdekelni a természettudományos tárgyak és közöttük is akadt két olyan tanuló, aki leszögezte, hogy nem az online oktatási környezet váltotta ki érdeklődésének fokozódását. „Az online oktatás miatt egyáltalán nem, azonkívül igen, változott. Jobban érdekelnek, mint korábban." „Pozitivan változott, de csak azért, mert olyan témához értünk a tananyagban, tehát nincs köze az online oktatásra való átálláshoz."

\subsection{Nehezebb-e digitális környezetben tanulni a matematikát?}

Minden diák válaszolt erre a kérdésre. Összesítve 59,26\% találja nehezebbnek online a matematika tanulását. A tagozatos tanulók 57,14\%-a, míg az alaptanterv szerint haladók 61,54\%-a érzi nehezebbnek digitális környezetben tanulni ezt a tantárgyat. A tanári magyarázat, a személyes kontaktus, az 
interakció hiánya egyértelmüen érezhető a kapott válaszokból. „Igen, nehezebb, mert ha valamit nem értünk nehezebb segitséget kapni." „Igen, sokszor nehéz egy újfajta feladatot megoldani és megérteni, mivel nem mutatja a tanár a levezetését." „Igen, több dolog is megnehezíti a matematika tanulását a digitális térben.” "Nehezebb, mert ahhoz vagyunk szokva, hogy folyamatosan látjuk a tanárokat és ez hiányzik az online oktatás során. Nincs közvetlen kapcsolatunk a tanárral, igy sokkal nehezebb a matematikát megérteni." „Részemröl ez egy egyértelmü igen, mert nekem alapból nehezebben megy ez a tantárgy és a digitális oktatás nem igazán könnyitette meg a dolgom a matematika megértésével kapcsolatban.” „Igen, föleg a geometriánál. A hagyományos oktatás alatt volt lehetöség arra, hogy a tanár megnézze a füzetünket, segitsen szerkeszteni, vagy a számológépen megmutatni, melyik gombbal mit lehet csinálni. Erre most nincs lehetöség." „Igen, személy szerint nehezebbnek gondolom. Nem annyira átlátható számomra.” "Igen, nehezebb. Sokszor van olyan, hogy óra után nem értem a tananyagot, de később szánok rá időt, hogy gyakoroljam és ezáltal megértem.” „, Sokkal nehezebb, nincs meg az, hogy kimegyünk a táblához és ott sokkal jobban megértjük és vizuálisan sem látjuk a tanár magyarázását."

A válaszadók 40,74\%-a nem találja nehezebbnek a matematika tanulását a távolléti oktatás alatt. Válaszaikból az derül ki, hogy aki korábban is könnyen vette az akadályokat, szerette a matematikát, jó érzéke van hozzá, most is jól boldogul. „A matematika az egyetlen tantárgy, amit nem érzek nehezebbnek digitális oktatás során." "Szerintem nem nehezebb, mert a tanár ugyanúgy mutatja az anyagot megosztott képernyövel.” „Szerintem nem, mert mindent ugyanúgy elmagyaráznak a tanárok.” „Szerintem nem, a tanár ugyanúgy, söt a geometriát érthetöbben is fel tudja rajzolni a megosztott képernyöre.” „Nem, mivel az órán részletes magyarázatot kapunk.” „Nem, véleményem szerint sokkal könnyebb." "Szerintem nem, mert ugyanúgy odafigyelek az órákra, mindig megirom a házikat, persze van olyan témakör, aminek az elsajátítása nem olyan egyszerü és lehet jobban át tudnánk venni személyes tanitás alatt, de szerintem meg lehet birkózni a feladattal."

A digitalizáló táblák az online oktatás esetén remekül integrálható oktatástechnikai eszközök. Használatukkal az a hatás kelthető, amely a jelenlegi helyzetben a legközelebb van a jelenléti oktatás nyújtotta élményhez. A OneNote vagy a Wacom táblákhoz ajánlott Bamboo Paper olyan virtuális jegyzetfüzetek, amelyekre a táblákhoz tartozó tollal valós időben tudunk írni és a képernyőmegosztás lehetőségével élve ezt a diákok is azonnal látják. Az elkészített jegyzetek elmenthetők, a diákok számára hozzáférhetővé tehetők. Kiderül a válaszokból, hogy a megkérdezett osztályokban a matematikát tanító tanárok használnak digitalizáló táblát. Emellett a GeoGebra nyílt forráskódú, ingyenesen hozzáférhető szoftvert is rendszeresen igénybe veszik és tanítványaikat is erre biztatják. ,,...nekünk Tanárnö egy rajzoló programot használ, ami ugyanolyan, mintha a táblára irna.” „,... a táblán keresztül mindent fel lehet rajzolni.” „A GeoGebrát használom rendszeresen, mert jóval egyszerübb, mint füzetben koordináta-rendszereket rajzolgatni. Valamint nagyszerü egy-egy házi ellenörzésére is.” „Teljes mértékben megvannak azok az eszközök, amivel online is meg lehet valósitani a matematika tanitását."

\subsection{Melyek azok a platformok, amelyeket a legszívesebben használtok az online tanulás során természettudományos tárgyak (matematika, biológia, kémia, fizika) esetén? Milyen elö- nyökkel bírnak?}

A számítógéppel támogatott tanulás egyik irányvonala az internetes tanulás, amely 2004-től, az egyszerü weboldalak dinamikussá válásától kezdődően indult robbanásszerủ fejlődésnek. Napjainkra dúskálunk az olyan tudásmegosztó portálokban, ahol jobbnál jobb interaktív elemekkel gazdagított, folyamatosan bővülő, szakmailag kimagasló színvonalú tartalmak érhetőek el bárki számára. A koronavírus-járvány által kikényszerített távolléti oktatás első ciklusában ezek a platformok az érdeklődés 
középpontjába kerültek. Azok a pedagógusok is elkezdték feltérképezni a rendelkezésre álló online lehetőségeket, akik korábban erre nem fordítottak különösebb figyelmet. A diákok által felsorolt felületek azt mutatják, hogy a tanuláshoz szükséges tartalmak, információk számukra könnyen hozzáférhetők, tudják, hogy hol keressék a válaszokat a felmerülő kérdések esetén. „Néha jobb, ha nem csak a tanár magyarázatát halljuk, mert ha több szempontól is megközelítünk egy témát, hamarabb meg lehet érteni." A tagozatos tanulók dupla annyi olyan weboldalt soroltak fel, amelyet szívesen látogatnak a hiányzó ismeretek megszerzésére vagy gyakorlás céljából, mint az alaptanterv szerint haladó diákok.

A korábban említett GeoGebra, amely egy dinamikus matematikai program nagy népszerüségnek örvend mindkét csoport esetén. A magyar nyelvü, bárki számára szabadon letölthető, folyamatos fejlesztés alatt lévő algebrai és geometriai oktatóprogram könnyen kezelhető, használata nem igényel magas szintü informatikai ismereteket, továbbá nagy számú kidolgozott GeoGebra tananyag is online elérhető, így az önálló tanulás támogatására is remekül használható komplex rendszer. A GeoGebra motivációs és szemléltető eszközként is használható. Az animációk a változtatható paraméterek segítségével elösegítik, hogy a diákok könnyebben megsejthessék, megérthessék, beláthassák az összefüggéseket, ezért a tanárok is szívesen használják. Az MTMI szakok hallgatói egyetemi éveik alatt általában több féléven keresztül tanulnak alapozó matematika tárgyakat. A GeoGebra használatában szerzett jártasság ezen tárgyak teljesítését is elősegíti. „A GeoGebrában mindent meg lehet csinálni, amit kézzel le lehet rajzolni és könnyü a kezelhetösége."

Egy másik ingyenesen és magyar nyelven is elérhetö, számos tudományterületet, közöttük a természettudományokat lefedő gyüjtemény a Khan Academy. amely gyakorló feladatokat, oktatóvideókat és személyre szabott tanulási összesítő táblát kínál regisztrált felhasználóinak. Modern, adaptív technológia segítségével követi nyomon a tanulási folyamatot a rendszer, amely felméri az erősségeket és a hiányosságokat, így lehetővé teszi, hogy a tanulók a saját tempójukban tanuljanak [6]. A magyar verzió is folyamatos fejlesztés alatt van, egyre több tartalom érhető el, azonban a világszerte nagy népszerüségnek örvendő, többezer oktatóvideót és feladatot tartalmazó eredeti, angol nyelvü változat teljes palettáját még messze nem vonultatja fel. Ezt a platformot csak tagozatos diák tüntette fel a válaszokban.

A YouTube 2005-ben kezdte meg müködését, és 2006-ban már milliós látogatottságú volt [6]. Az oldal tartalmának nagy része ingyenesen elérhetö. A megalakulást követően rövid időn belül tematikus videócsatornák is létrejöttek. A feltöltött videók közös jellemzöje, hogy nem túl hosszúak, látványosak. Mind a tagozatos, mind az alaptanterv szerint tanulók kedvelik, és gyakran nézik a feltöltött videókat. „Én többnyire a YouTube-on nézek videókat, ha nem értek valamit vagy nem találok valami érdekeset. Néha felkukkantok a Khan Academyre is.” „A YouTube videók sokat segitenek. Föleg kémiából, ha kísérlet bemutatására kerül sor.” „A YouTube-ra feltöltött kísérletek, videók nagyban segítik néhány dolog megértését.” „Olyan kísérleteket is meg tudok nézni a YouTube-on, amit az iskolában nem csinálnak."

A többnyelvü online világenciklopédia, a Wikipédia használata is kedvelt a válaszadók mindkét csoportjánál. A Fizipédia, a BME TTK Fizika Tanszéke által üzemeltetett, folyamatosan frissülő portál is megjelent a tagozatos diákok által küldött válaszokban. A weboldal fontos része a több mint 100 kísérleti videót tartalmazó fizika videótár, amely középiskolásoknak, fizika iránt érdeklődőknek is hasznos, szabadon elérhető tananyag [7]. Az nkp.hu az Oktatási Hivatal Nemzeti Köznevelési Programjához uniós forrásból létrehozott portál. Feladatokat, videókat, animációkat és linkeket tartalmaz, továbbá az okostankönyvek mellett médiatárral is rendelkezik [8]. Egyelöre nem fedi le a teljes középiskolai tananyagot, így használhatósága korlátozott. 
A nonprofit cégek által múködtetett oldalak mellett természetesen találunk olyan platformokat is, amelyek szabadon csak részben hozzáférhetőek, a teljes felület használatához a regisztráción túlmenően előfizetéssel kell rendelkezni. Ezek egyike például a mozaWeb, amely a Mozaik Kiadó Kft. által uniós támogatással létrehozott szoftver. Ez a platform új generációs oktatást tesz lehetővé a hálózatba integrált digitális tananyagokból felépített rendszerével, valamint az igényes 3D-s minivideókkal [9]. Az integrált játékos elemek, feladatok miatt a játék alapú oktatás igényeinek is megfelel. A mateking.hu ugyancsak korlátozott hozzáférésủ oldal. Középiskolai matek kurzusa 439 rövid epizód és 12 teszt segítségével 40 témakörön keresztül vezeti végig a felhasználót a teljes középiskolai tananyagon. „A mateking.hu egy jó oldal.” 2020. március 15-től júniusig az üzemeltetők ingyenesen elérhetővé tették a teljes Középiskolai matek tantárgyat, így az iskolabezárás alatt napi 50-60 ezer diák kereste fel az oldalt. A matematika érettségi előtt egyetlen nap 87 ezer látogatója volt a portálnak [10].

A tanulás mellett a számonkérések problémáját is meg kellett oldani az online oktatás során. Nem meglepö, hogy a kapott válaszokban több olyan online felületet is megjelöltek a diákok, amelyet a leginkább kedvelnek a dolgozatírások, felelések alkalmával. A Redmenta egy olyan magyar nyelvü feladatlapkészítő alkalmazás, amely megkönnyíti és gyorsabbá teszi az oktatók munkáját a számonkérések során. Használata regisztrációhoz kötött, de ingyenes [11]. ,,Redmenta, az elönye, hogy átlátható, eredményorientált és könnyebb dolgozatot irni ezen a platformon.” „Redmenta, folyamatosan látszik, hogy mennyi idő van hátra a dolgozatok során és különbözö fajta feladatokat lehet késziteni benne.” A gamer fiatalok között nagyon népszerü Discord egy ingyenes, de angol nyelvü beszélgetö alkalmazás, amely biztosítani tudja a szöveges, a kép- és videó-, valamint az audiokommunikációt is. Használata regisztrációhoz kötött. A kényszerü online oktatás alatt kiderült, hogy kiválóan használható valós idejü tanár-diák kommunikációra és virtuális tanteremként is [12]. „Én a Discord-ot szerettem a legjobban, hiszen azt már korábban is használtam." A Facebook Messenger vagy röviden Messenger egy díjmentesen használható online üzenetküldő alkalmazás és platform. A felhasználók üzeneteket, fényképeket, videókat, hanganyagokat és fájlokat küldhetnek egymásnak, továbbá véleményezhetik mások bejegyzéseit. A szolgáltatás támogatja a hang-és videóhívásokat is, ezért szóbeli számonkérések alkalmával jól használható [12]. „A Messenger felelésre alkalmas, nem szokott baj lenni vele."

\subsection{Milyen eszközök támogatják leginkább a digitális környezetben a tanítási-tanulási folyama- tot a természettudományos tárgyak esetén?}

Erre a kérdésre döntő hányadban a számítógép, laptop, tablet, kamera, mikrofon és telefon válaszok érkeztek függetlenül attól, hogy alaptanterv szerint vagy tagozaton tanul-e a válaszadó. Tanári oldalról pedig a digitalizáló tábla szerepel még a felsorolásokban. Ezek az eszközök nyilván nem csak a természettudományos tárgyak esetén segítik a tanítási-tanulási folyamatot, hanem a többi tantárgy esetén is. „A laptopom és a telefonom, ezek mellett viszont ugyanúgy a könyvek és füzetek jegyzetei segitenek." Bár a kérdés megfogalmazásakor IKT eszközökre gondoltunk, kellemesen meglepödtünk azon, hogy a válaszadók egy kisebb csoportjánál megjelentek a hagyományos oktatás klasszikus kellékei: egy jó vázlat, az adott tárgy tankönyve, különböző könyvek, négyjegyű függvénytáblázat. Az online órák során gyakori, hogy a pedagógus megadja a forrásokat az iskolai tankönyvböl is, így, ha a tanuló onnan szeretne tájékozódni, tudja, hogy mit hol talál meg. Gyakori a feladatmegoldás a tankönyvekböl, feladatgyüjteményekből, tehát azokat is használni kell. A jelenléti oktatáshoz kapcsolódó eszközkészlet lényegében kibővült a közösségi oktatásban alkalmazott elemekkel. A bemutatókkal, vázlatokkal, videókkal színesített órák új keretet kaptak, de tartalmukat tekintve változatlanok maradtak. 


\subsection{Mi az, ami a jelenlegi helyzetben nem segíti az oktatást, hanem inkább hátráltatja?}

Az eszközhiány csak elvétve jelenik meg a válaszokban, amiből egyértelműen kiderül, hogy a felmérésben résztvevők általában rendelkeznek a távolléti oktatáshoz szükséges technikai felszereltséggel. „A megfelelö eszközök hiánya az, ami leginkább hátráltatja a digitális oktatást. Ezek nélkül nehezebb dolga van mind a diákoknak, mind a tanároknak."

A megbízhatóan müködő internet és a folyamatos áramszolgáltatás fontossága azonban itt ismételten visszaköszön, úgy, mint korábban a második kérdésnél, ahol a nehézségeket összegeztük. „Ha elmegy a net, akkor lemaradsz mindenröl." „Az internet nagyon le van terhelve, folyamatosan akadozik.” "Vannak buktatók az online oktatásban. Akármikor elmehet az internet, ami sajnos mondjuk egy dolgozat irása során nem túl elönyös."

Sarkalatos kérdés a diákok szempontjából a tárgyalt tananyag mennyisége és az órák minősége. „Néhány tanár nagyon gyorsan magyaráz, mert nem lát minket és nem érzékeli, hogy túl gyorsan halad." „Ha a tanárok nem kérik a kamera bekapcsolását az órán, akkor nem látják a diákok arckifejezését, hogy értik-e az anyagot vagy nem." „A tanárok nem mindig érzik, látják, hogy milyen gyorsan tudjuk leírni, amit diktálnak, így sokszor lemaradunk és vissza kell kérdezni, ami lassítja az órákat." „A tanárok olyan órákat is megtartanak, amit fölösleges lenne, mert olyan gyorsan mondják az anyagot, hogy úgyis iskolán kívül kell leírnom, ezzel sokkal kevesebb szabadidöm marad, valamint minden tanár azt hiszi, hogy itthon ülve könnyebb tanulni, ezért sokkal nagyobbak az elvárásaik velünk szemben, ami nagyon stresszessé tesz minket.” ", Az olyan órák (hátráltatják az oktatást), amik nem interaktivak, hanem csak elmondják az anyagot és vége." „A monoton órák."

A dolgozatokkal kapcsolatos tanári magatartás is a hátráltató tényezők egyikeként jelent meg a válaszokban. „A tanárok bizalmatlansága a diákok felé, miszerint számonkérések esetén a diákok részéröl nem a valós tudás visszaadása valósul meg.” „Dolgozat közben sok lehet a csalás.” Online dolgozatok esetén nagy arra a kísértés, hogy a könnyebbik utat válasszák a diákok. A csalás ténye sokszor bebizonyosodott már az elmúlt időszakban, ezért nem véletlenül gondolkodnak így a tanárok. Ugyanakkor nem csal mindenki.

A hétköznapok egyhangúsága, a bezártság és az elszigeteltség a kamaszok többsége számára nehézséget okoz. „Az otthonlét, a gyakori rendszertelenség eléggé hátráltat.” „Egy bizonyos idő után unalmassá válnak a hétköznapok és a tanulás is. Nincs az a természetes verseny a diákok között, hogy ki tud többet...?, mert ha rendes oktatás lenne, akkor a diákokat ez ösztönözné, hogy én többet akarok tudni, mint a másik. A digitális oktatásban ez elveszett." „Az osztálytársak hiánya, mert régen sokat segítettünk egymásnak, így viszont alig beszélünk. Az is hátrány, hogy napi 7-8 órát kell a gép elött ülni és irni folyamatosan. Ez monotonná teszi a tanulás folyamatát, elkedvetlenit.” „Megnézek egy kisérleti videót... hát nem olyan, mint élöben."

\section{4. Összefoglalás}

A digitális oktatásra vonatkozó nyolc kérdéses kérdőívre 54 válasz érkezett e-mailben. Az első három kérdés során a digitális oktatással kapcsolatos általános benyomásokra, tapasztalatokra fókuszáltunk, valamint a motiváció megvalósíthatóságát mértük fel 10. évfolyamra járó diákok esetén. Négy kérdés kapcsolódott közvetlenül az MTMI tudományterülethez tartozó tantárgyakhoz. Kérdéseink az érdeklödési kör változására, a digitális környezetben való tanulásra, valamint a gyakran használt online platformok feltárására irányultak. Könnyű dolgunk volt, hiszen a felmérésben aktívan résztvevők bőséges információval láttak el minket valamennyi kérdés esetén, így részletes kép alakult ki bennünk arról, hogy ez a korosztály hogyan éli meg a járványveszély miatt bevezetett online oktatás hétköznapjait. 
Megismertük, hogy melyek azok a szegmensek, amelyeken lehet és érdemes javítani és melyek azok, amelyek csak a jelenléti oktatás újraindításával rendeződhetnek. Tavasszal a tanulóknak még számos nehézséggel kellett megküzdeni a távolléti oktatás velejárójaként, őszre azonban tanárok, diákok egyaránt hozzászoktak a megváltozott feltételekhez, a bevált jó gyakorlatok alkalmazásával zökkenőmentesebben vették az akadályokat, mint korábban. Ebben döntő fontosságú lépés volt az iskola által egységessé tett online platform, amely jól kezelhető, átlátható keretrendszert biztosít tanárnak, tanulónak egyaránt. A természettudományos tárgyak közül a matematika tanulása határozottan nehezebbnek bizonyul online környezetben, azonban a fizika, biológia, kémia tanítását sem találják eléggé hatékonynak a diákok. A jelenléti oktatás biztosította személyes kontaktus egyértelmüen felértékelődött. Hiányoznak az eddig teljesen természetesnek tekintett apró gesztusok, az azonnali segítségkérés és válaszadás lehetősége, a visszacsatolás, a folyamatos tanári kontroll. A barátokkal való napi kapcsolat, és az osztályközösségen belüli természetes módon kialakuló versengés elveszítése is érzékenyen érinti a kamaszokat. A természettudományok iránti érdeklődés azonban szignifikánsan nem változott meg az online oktatás időszaka alatt sem a tagozaton, sem az alaptanterv szerint haladók esetén. Az MTMI tudományterület tehát várhatóan nem szenved komolyabb veszteségeket, hiszen azok a diákok, akik az online oktatás előtt az MTMI szakok egyikén tervezték továbbtanulásukat a nehézségek ellenére sem változtatnak terveiken. Ugyanúgy tanulnak, terveznek; függetlenül attól, hogy jelenléti vagy online környezetben zajlik-e az oktatásuk.

\section{Köszönetnyilvánítás}

A cikkben ismertetett kutató munka az EFOP-3.4.4-16-2017-00008 jelü „Tudás - Vár a Miskolci Egyetem! A felsőoktatásba való bekerülést elősegítő készségfejlesztő és kommunikációs programok megvalósítása, valamint az MTMI szakok népszerüsítése a felsőoktatásban” projekt részeként - a Széchenyi 2020 keretében - az Európai Unió támogatásával, az Európai Szociális Alap társfinanszírozásával valósult meg.

\section{Irodalom}

[1] Mik azok az MTMI szakok? [Online] http://tanuljrealt.pte.hu/altalanos-infok/mik-azok-az-mtmiszakok/

[2] Károly G.: Már nem a szakemberhiány a legnagyobb probléma, Index, 2020.10. 20. [Online] https://index.hu/gazdasag/2020/10/20/pwc_felmeres_koronavirus_munkaerohiany/

[3] Körei A., Szilágyi Sz.: Didaktikai játékok integrálásának lehetőségei a felsőoktatásban, Multidiszciplináris Tudományok: A Miskolci Egyetem Közleménye (2062-9737): 10 (3) pp. 221-232 (2020), https://doi.org/10.35925/j.multi.2020.3.27

[4] Drippey-Dévai J.: „Miért nem tanulsz?!” - A tanulási motiváció, mindset pszichológia, [Online], https://mindsetpszichologia.hu/miert-nem-tanulsz-a-tanulasi-motivacio

[5] Gábris, Z.: Gamifikáció az oktatásban - avagy hogyan motiváljuk tanulásra az Alfa és Z generációt?, [Online], https://mindsetpszichologia.hu/2019/06/17/gamifikacio-az-oktatasban-avagyhogyan-motivaljuk-tanulasra-az-alfa-es-a-z-generaciot/

[6] Sváb, Á.: Új online tanulási környezet: a közösségi tanulás, Sokszínü pedagógiai kultúra: II. Neveléstudományi és szakmódszertani konferencia, Komárno, Szlovákia: International Research Institute, 2014, pp. 359-364, ISBN 978-80-89691-05-0 
[7] Fizipédia: a BME TTK Fizikai Intézet által üzemeltetett oktatási portál, https://fizipedia.bme.hu/index.php/Kezd\%C5\%91lap

[8] Nemzeti Köznevelési Portál: az OH által üzemeltetett oktatási portál, https://www.nkp.hu/

[9] mozaWeb: a Mozaik Kiadó Kft. által üzemeltett oktatási platform, https://www.mozaweb.hu/

[10] mateking.hu: Matek egyszerüen, https://www.mateking.hu/

[11] Király S.: Redmenta, az intelligens oktatási asszisztens, ÚJ KÖZNEVELÉS, 73. évf.: 5. szám, pp. 44-48., (2017), ISSN 2064-0625

[12] Távoktatás tanári szemmel, [Online], https://mdoe.hu/digitalis-oktatas/tavoktatas-tanariszemmel/ 